\title{
Influence of YEA-SACC 1026 Probiotic on Meat Quality in Chicken Broilers
}

\author{
Ionel TOADER*, Aurel ŞARA, Mihai BENȚEA, Mirela CADAR \\ Faculty of Animal Science and Biotechnologies, University of Agricultural Sciences and \\ Veterinary Medicine, 3-5 Mănăștur Street, 400372 Cluj-Napoca, Romania \\ * corresponding author: tehnicianionel@gmail.com \\ Bulletin UASVM Animal Science and Biotechnologies 74(1)/ 2017 \\ Print ISSN 1843-5262; Electronic ISSN 1843-536X \\ DOI:10.15835/buasvmcn-asb: 12291
}

\begin{abstract}
The use of probiotics, as fodder supplement for chickens, could stimulate meat quality that is a very important criterion especially for human consumption markets. The study had in view the effects of YEA-SACC 1026 probiotic product on meat quality in chicken broilers. There were studied 75 meat chickens of Ross-308 hybrid grouped on three lots of 25 capita/lot during an experimental period of 42 days. In the mixed fodder of experimental lots was added YEA-SACC 1026 probiotic in proportion of $0.1 \%$ in lot L1(E) and in proportion of $0.25 \%$ in lot L2(E). In the experiment end were effected control slaughtering of 5 chickens per each lot, to establish the meat quality by trenching and meat chemical composition. After YEA-SACC 1026 probiotic administration, as fodder supplement, was improved the chicken meat quality by increasing the weight of superior quality meat in carcass. The obtained results confirm the favourable effects of probiotics on chicken meat production and its quality
\end{abstract}

Keywords: chicken broilers, YEA-SACC 1026, meat quality

\section{Introduction}

Antibiotics were used as growing promoter to prevent diseases and stress and to sustain breeding performances in commercial broiler farms. In many countries, the antibiotic use as growing promoter was forbidden because of antibioticresistant genes' activation and their effects on human health status (EC Regulation No. 1831 2003). In last years, an important interest was focused on probiotics use as alternative solution to antibiotics in animal nutrition. Saccharomyces cerevisiae was grown on yellow corn, malt and molasses and has in composition minimum 28\% pure protein, minimum $6 \%$ pure fat, maximum $4 \%$ pure fibres, maximum $8 \%$ dry substance and contains minimum 5 million cells/gram and its commercial name is YEA-SACC1026. Probiotics are used as fodder additives in animal nutrition to realize biological protection of the host organism, to stimulate appetite, digestion processes and productive performances (Nawaz et al., 2016). Also, probiotics inhibit the growth of certain pathogens, which could produce toxic compounds (Patterson and Burkholder, 2003).

\section{Aims and objectives}

The study had in view the effects of YEA-SACC 1026 probiotic product on meat quality in chicken broilers.

\section{Material and methods}

The researches were effected on 75 meat chickens of Ross-308 hybrid grouped on three lots of 25 capita/lot during an experimental period of 42 days. In the mixed fodder of lot L1(E) was added powdery YEA-SACC 1026 probiotic (囚Altech Romania) in proportion of $0.1 \%$ for 42 days. In the lot L2(E) was added in mixed fodder the powdery YEA-SACC 1026 probiotic (®Altech Romania) in proportion of $0.25 \%$ for 42 days. For 
Tab. 1. Average values and variability of slaughtering efficiency in meat chickens

\begin{tabular}{|c|c|c|c|c|c|}
\hline \multirow{3}{*}{\multicolumn{2}{|c|}{ Lots }} & \multirow{3}{*}{$\mathrm{n}$} & \multicolumn{3}{|c|}{ Slaughtering efficiency } \\
\hline & & & \multicolumn{2}{|c|}{ Absolute } & \multirow{2}{*}{$\begin{array}{c}\text { Relative } \\
\%\end{array}$} \\
\hline & & & $\mathrm{X}+\mathrm{Sx}$ & $\mathrm{V} \%$ & \\
\hline \multicolumn{2}{|l|}{ L(M) control } & 5 & $75.93 \pm 1.92$ & 5.66 & 100.00 \\
\hline L1(E) YEA-SACC 1026 & $0.1 \%$ & 5 & $79.62^{* *} \pm 0.65$ & 1.82 & 104.85 \\
\hline L2(E) YEA-SACC 1026 & $0.25 \%$ & 5 & $79.54^{* *} \pm 2.02$ & 5.67 & 104.75 \\
\hline
\end{tabular}

Tab. 2. The results of carcass trenching in meat chickens

\begin{tabular}{cccccccc}
\hline \multirow{2}{*}{ Lots } & \multicolumn{5}{c}{ Meat quality (\% of carcass) } \\
\cline { 3 - 8 } & & \multicolumn{2}{c}{$\begin{array}{c}\text { I } \\
\text { chest+thigh+shank }\end{array}$} & $\begin{array}{c}\text { II } \\
\text { back+wings }\end{array}$ & \multicolumn{2}{c}{$\begin{array}{c}\text { III } \\
\text { head+neck+tibia }\end{array}$} \\
\cline { 2 - 8 } & absolute & relative & absolute & relative & absolute & relative \\
\hline L(M) control & 60.50 & 100 & 27.60 & 100 & 11.9 & 100 \\
\hline L1(E) YEA-SACC 1026 & $0.1 \%$ & 60.62 & 100.20 & 27.60 & 100 & 11.79 & 99.07 \\
\hline L2(E) YEA-SACC 1026 & $0.25 \%$ & 60.89 & 100.64 & 27.23 & 98.66 & 11.88 & 99.83 \\
\hline
\end{tabular}

the control lot L(M) was used only mixed fodder. In the experiment end, there was effected control slaughtering of 5 chickens per each lot, to establish the meat quality by trenching and entire carcass weights and their parts: head, neck, tibia, chest, thigh + shank, back and wings. The experimental data were statistically analysed with Student test by GraphPad InStat ver.3.10 program.

\section{Results and discussion}

The average values and variability of slaughtering efficiency in meat chickens are presented in Table1, and from the data comes out that absolute slaughtering efficiency is almost equal in experimental lots and smaller in control one. As concerns the values of commercial yield, they follow the same way as slaughtering efficiency, the greatest value being for chickens of lot L1(E) (YEASACC $10260.1 \%$ ) with an average of $83.69 \%$, the next one being in chickens of lot L2(E) (YEA-SACC $10260.25 \%$ ) with an average of $83.43 \%$, and the smallest one in control lot L(M) with $80.29 \%$. There are distinct significant differences $\left({ }^{* *}\right)$ between experimental lots and control one. When the probiotic supplement YEA-SACC 1026 was in proportion of $0.20 \%$, Sara et al. (2006) obtained an average value of commercial yield of $81.85 \%$, and in control group an average of $78.33 \%$.

From the data presented in Table 2 it can be observed that in chickens of lots L1(E) and L2(E) the weight in carcass of superior quality meat (quality I and II) is greater (88.22\%, respectively $88,12 \%)$ than in control lot $\mathrm{L}(\mathrm{M})$ chickens $(88.1 \%)$. Sara et al. (2006) obtained only $52.73 \%$ for $1^{\text {st }}$ quality meat (YEA-SACC 1026 0.20\%).

\section{Conclusion}

From the presented data comes out that administration of YEA-SACC 1026 probiotic in the chicken broilers' fodder improved:

the slaughtering efficiency, the commercial yield, the weight of superior quality meat

in carcass presented in Table 2.

\section{REFERENCES}

1. EC Regulation No. 1831/2003 of European Parliament and the Council of 22 Sept 2003 on additives for use in animal nutrition. Off. J. Eur. Union. Page L268/36 in OJEU of 10/18/2003. Brussels, 0020Belgium.

2. Patterson HA, Burkholder KM (2003). Application of prebiotic and prebiotics in poultry production. Poult Sci 82: 627-631.

3. Sara A, Odagiu A, Bentea M, Dinea M, Panta L (2006). The influence of the probiotic Yea-Sacc-1026 and organic selenium (Sel-Plex) on slaughter indices in broiler chickens, Bull. USAMV-CN, 63:234-237.

4. Nawaz H, Abbas Irshad, Mubarak A (2016). Effect of probiotics on growth performance, nutrient digestibility and carcass characteristics in broilers. Journal of Animal \& Plant Sciences 26(3): 599-604. 